\title{
Absorption Capacity of Copper and Lead in the Case of Phragmites Australis Plant Species
}

\author{
ALEXANDRA DANA CHITIMUS', FLORIN MARIAN NEDEFF ${ }^{*}$, ION SANDU ${ }^{3,4}$, CRISTIAN RADU², EMILIAN MOSNEGUTU1, \\ NARCIS BARSAN ${ }^{1 *}$, IOAN GABRIEL SANDU ${ }^{4,5}$, CLAUDIA TOMOZEI ${ }^{1}$ \\ ${ }^{1}$ Vasile Alecsandri University of Bacau, Faculty of Engineering, 157 Calea Marasesti, 600115 Bacau, Romania \\ 2 Romanian Waters - National Administration of Siret Basin, 1 Cuza Voda Str., 600274 Bacau, Romania \\ ${ }^{3}$ Alexandru Ioan Cuza University of Iasi, Arheoinvest Interdisciplinary Platform, Scientific Investigation Laboratory, \\ 11 Carol I Blvd., 700506 lasi, Romania \\ ${ }^{4}$ Romanian Inventors Forum, 3 Sf. Petru Movila Str., Bloc L11, III/3, 700089 lasi, Romania \\ ${ }^{5}$ Gheorghe Asachi Technical University of Iasi, Materials Science and Engineering Faculty, 53A D. Mangeron Blvd., 700050 lasi, \\ Romania
}

The main objective of the current research is to determine the absorption capacity of heavy metals (copper and lead) in the case of Phragmites Australis plant species (root, stalk, leaf, flower). The plant samples was taken from the Moldova and Siret Rivers, belonging to the Siret hydrographic basin, respectively upstream of Roman city, Romania-Siret River, downstream Roman city-Moldova River, downstream confluence Moldova/ Siret-Siret River and Dragesti-Siret River. A high absorption capacity of copper was recorded, in the case of Phragmites Australis plant species (especially in the root of the plant for all point analysed). A very higher absorption capacity of lead was recorded, in the flower, in the case of Phragmites Australis plant species (1.45 $\div 39.56 \mathrm{mg} / \mathrm{kg}$ dry matter) for all point analysed.

Keywords: copper, lead, absorption capacity, Phragmites Australis

The pollution of the environment with heavy metals is caused by the industrial activity, transports or by various other human activities. Pollutants analyzed in this paper belong to the category of persistent pollutants (they cannot be removed or destroyed from the matrices they contaminate), which leads to their bioaccumulation in the organism of plants and animals, creating risks for public health [1-19].

Some risk assessment procedures are based on calculations involving the distribution, transport and behavior of contaminants in the soil-plant system, including physico-chemical characteristics of the soil, to predict the bioavailability of contaminants for the cultivated plants [ 8 , 9, 20-25].

The absorption of heavy metals at the root level is of two types [8, 9, 26-33]:
- passive - through the diffusion of ions from the soil solution into the rootendoderm;

- active - it is realized at the expense of energy, against the concentration gradient.

Some authors argue that the absorption of chemical elements is controlled by processes inside the root, at a certain concentration generally distributed in soil solution. The main factors that influence the absorption process of the metals are represented by the activity of the ions in the solution and by the presence of some constituents of the soil, such as microorganisms, which by association with the roots produce organic compounds that facilitate the release of chemical elements in the soil [34-42].

This paper describes the absorption capacity of heavy metals (copper and lead) in the case of Phragmites Australis plant species (root, stalk, leaf, flower).

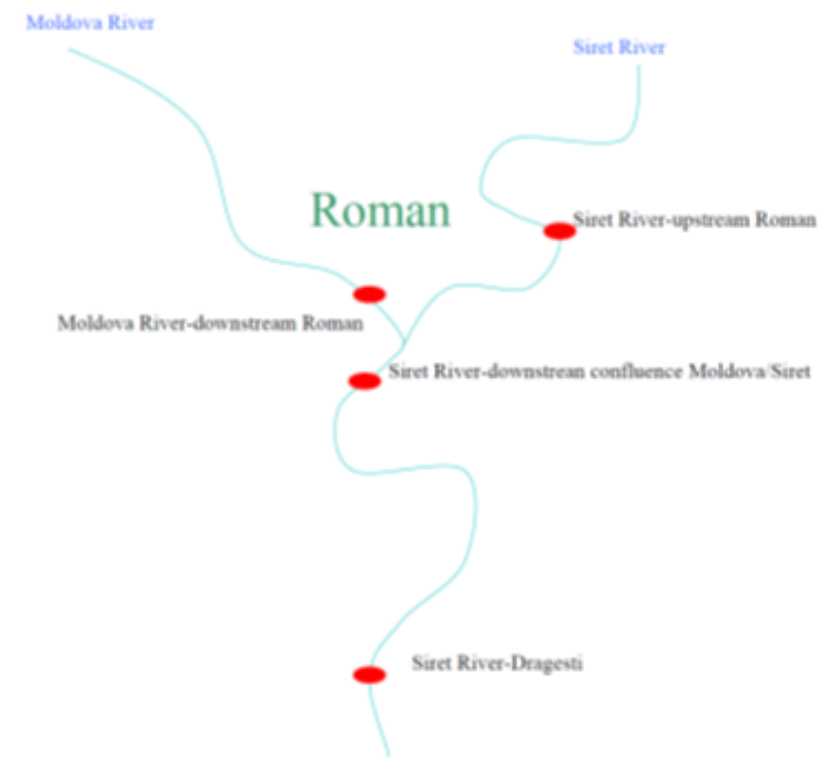

Fig. 1. Sections taken into consideration for taking samples of soil and plants along the Moldova and Siret Rivers [3]

\footnotetext{
*email: florin_nedeff@ub.ro, Phone: +40745157751; narcis.barsan@ub.ro,Phone: +40742325012
} 


\section{Experimental part}

Sections taken into consideration for taking samples of plants are presented in Figure 1. The sampling of vegetation was took from four locations/areas along the Moldova and Siret Rivers, belonging to the Siret hydrographic basin (upstream of Roman city, Romania-Siret River, downstream Roman city - Moldova River, downstream confluence Moldova/Siret- Siret River and Dragesti-Siret River) from the banks of the tributaries [3].

Phragmites Australis (common reed, Figure 2) is a perennial herbaceous plant from the Gramineae family (Poaceae), having a rigid stalk of about 1-4m, green-bluish lanceolate leaves and flowers laid out in tassels and is a good accumulator of heavy metals and hydrocarbons [3].

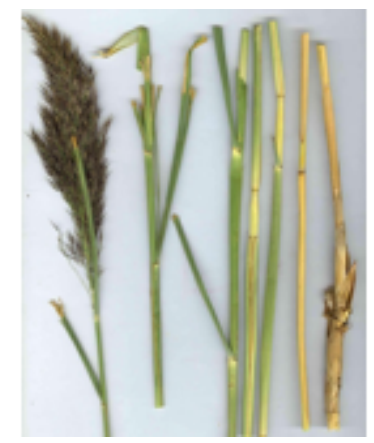

Fig. 2. Phragmites Australis [3]

Plants samples were taken for three levels [3]:

- minimum level: soil-water interface level of $0 \mathrm{~cm}$;

- medium level: soil-water interface level of $50 \mathrm{~cm}$, on the river bank;

- maximum level: soil-water interface level of $100 \mathrm{~cm}$, on the river bank.

The copper and lead content in the case of Phragmites australis plant species has been determined by using the atomic absorption spectrometer (AAS), ZEENIT AAS version (Figure 3) [3, 43].

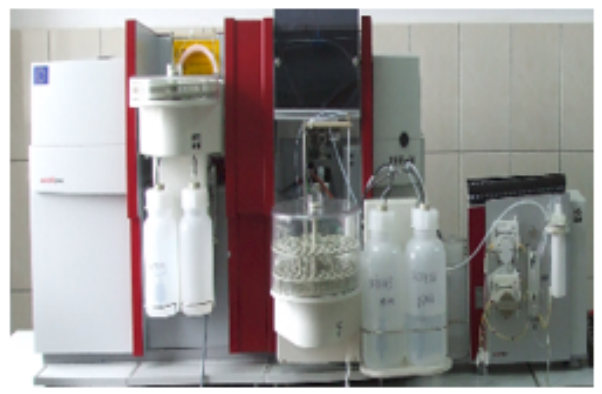

Fig. 3. Atomic absorption spectrometer (AAS), Zeenit 700 version $[3,38]$

\section{Results and discussions}

Figure 4 represents graphically the absorption capacity of copper from the soil in the case of Phragmites Australis

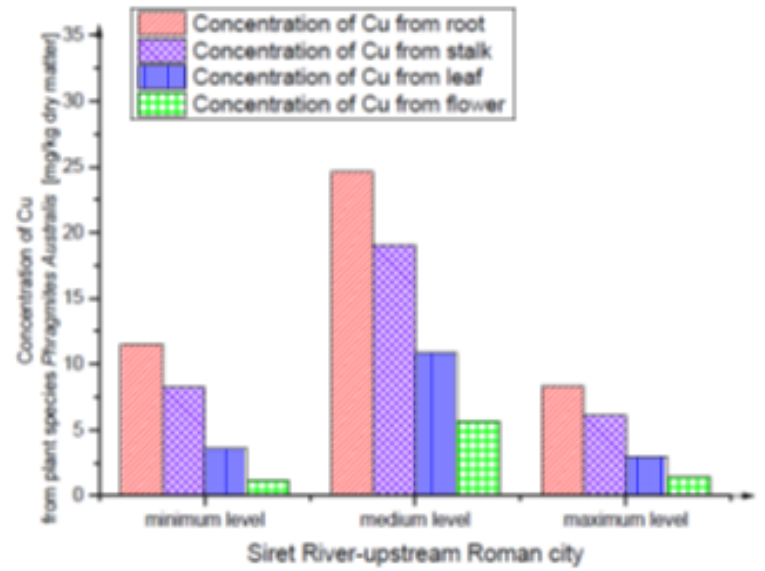

Fig. 4. The absorption capacity of coppr from the soil in the case of Phragmites Australis plant species (root, stalk, leaf, flower) in the sampling point Siret River - upstream of Roman city plant species (root, stalk, leaf, flower) in the sampling point Siret River - upstream of Roman city.

The highest absorption capacity of copper in the sampling point Siret River - upstream of Roman city, was detected in the root of Phragmites Australis plant species, and the lowestabsorption capacity of copper was observed in the flower.

The percentage values of the copper concentration determined in the stem, leaf and flower compared with the root of the Phragmites Australis plant species for the sampling point Siret River - upstream of Roman city, was:

a-steam (for the minimum level of soil-water interface, it was $28.33 \%$ lower than in the root of plant; for the medium level of soil-water interface, it was $22.75 \%$ lower than in the root of plant and for the maximum level of soilwater interface, it was $26.73 \%$ lower than in the root of plant);

b-leaf (for the minimum level of soil-water interface, it was $68.89 \%$ lower than in the root of plant; for the medium level of soil-water interface, it was $55.86 \%$ lower than in the root of plant and for the maximum level of soil-water interface, it was $64.74 \%$ lower than in the root of plant);

c -flower (for the minimum level of soil-water interface, it was $89.77 \%$ lower than in the root of plant; for the medium level of soil-water interface, it was $76.83 \%$ lower than in the root of plant and for the maximum level of soilwater interface, it was $82.61 \%$ lower than in the root of plant).

Figure 5 represents graphically the absorption capacity of lead from the soil in the case of Phragmites Australis plant species (root, stalk, leaf, flower) in the sampling point Siret River - upstream of Roman city.

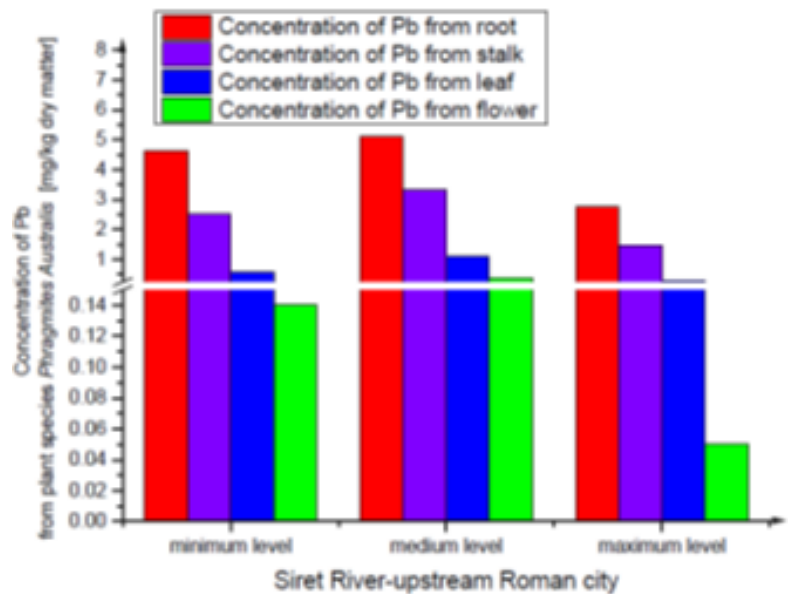

Fig. 5. The absorption capacity of lead from the soil in the case of Phragmites Australis plant species (root, stalk, leaf, flower) in the sampling point Siret River - upstream of Roman city

The percentage values of the lead concentration determined in the stem, leaf and flower compared with the root of the Phragmites Australis plant species for the sampling point Siret River - upstream of Roman city, was: a-steam (for the minimum level of soil-water interface, it was $54.19 \%$ of concentration from the root of plant; for the medium level of soil-water interface, it was $65.36 \%$ of concentration from the root of plant and for the maximum level of soil-water interface, it was $52.72 \%$ of concentration from the root of plant);

$\mathrm{b}$-leaf (for the minimum level of soil-water interface, it was $12.68 \%$ of concentration from the root of plant; for the medium level of soil-water interface, it was $21.91 \%$ of concentration from the root of plant and for the maximum level of soil-water interface, it was $10.18 \%$ of concentration from the root of plant); 
Table 1

THE EXPERIMENTAL VALUES DETERMINED FOR ABSORPTION CAPACITY OF COPPER AND LEAD FROM

THE SOIL IN THE CASE OF PHRAGMITES AUSTRALIS PLANT SPECIES (ROOT, STALK, LEAF, FLOWER) IN THE SAMPLING POINT DOWNSTREAM MOLDOVA RIVER-ROMAN CITY

\begin{tabular}{|c|c|c|c|c|c|c|c|c|c|}
\hline \multirow{2}{*}{ Location } & \multirow{2}{*}{ Level } & \multicolumn{4}{|c|}{$\begin{array}{c}\mathrm{Cu} \\
{[\mathrm{mg} / \mathrm{kg} \text { dry matter] }}\end{array}$} & \multicolumn{4}{|c|}{$\begin{array}{c}\mathrm{Pb} \\
{[\mathrm{mg} / \mathrm{kg} \text { dry matter] }}\end{array}$} \\
\hline & & Root & Stalk & Leaf & Flower & Root & Stalk & Leaf & Flower \\
\hline \multirow{3}{*}{$\begin{array}{l}\text { downstream } \\
\text { Moldova } \\
\text { River- } \\
\text { Roman city }\end{array}$} & $\begin{array}{c}\text { minimum level of } \\
\text { soil-water } \\
\text { interface }(0 \mathrm{~cm})\end{array}$ & 20.93 & 15.17 & 8.99 & 5.87 & 30.16 & 22.41 & 5.9 & 4.56 \\
\hline & $\begin{array}{l}\text { medium level of } \\
\text { soil-water } \\
\text { interface }(50 \mathrm{~cm})\end{array}$ & 23.4 & 18.53 & 11.25 & 7.64 & 14.21 & 9.25 & 5.27 & 3.14 \\
\hline & $\begin{array}{l}\text { maximum level of } \\
\text { soil-water } \\
\text { interface }(100 \mathrm{~cm})\end{array}$ & 25.29 & 21.49 & 14.34 & 8.25 & 22.45 & 13.84 & 8.19 & 6.41 \\
\hline
\end{tabular}

c -flower ( for the minimum level of soil-water interface, it was $3.01 \%$ of concentration from the root of plant; for the medium level of soil-water interface, it was $7.43 \%$ of concentration from the root of plant and for the maximum level of soil-water interface, it was $1.81 \%$ of concentration from the root of plant).

Table 1 present the experimental values determined for absorption capacity of copper and lead from the soil in the case of Phragmites Australis plant species (root, stalk, leaf, flower) in the sampling point downstream Moldova RiverRoman city.

The highest absorption capacity of copper from the soil, in downstream Moldova River- Roman city, was detected in the root of Phragmites Australis plant species (for the minimum level of soil-water interface, it was $356.55 \%$ higher than in the flower of plant), whereas the lowest absorption capacity levels of copper were observed in its leaf and flower.

The highest absorption capacity of lead from the soil, in downstream Moldova River- Roman city, was detected in the root of Phragmites Australis plant species (for the minimum level of soil-water interface, it was $456 \%$ higher than in the flower of plant), whereas the lowest absorption capacity levels of lead were observed in its leaf and flower.

Figure 6 represents graphically the absorption capacity of copper from the soil in the case of Phragmites Australis plant species (root, stalk, leaf, flower) in the sampling point Siret River - downstream confluence Moldova/Siret.

The percentage values of the copper concentration determined in the stem, leaf and flower compared with the root of the Phragmites Australis plant species for the sampling point Siret River - downstream confluence Moldova/Siret, was:

a - steam (for the minimum level of soil-water interface, it was $24.87 \%$ lower than in the root of plant; for the medium level of soil-water interface, it was $35.63 \%$ lower than in the root of plant and for the maximum level of soil-

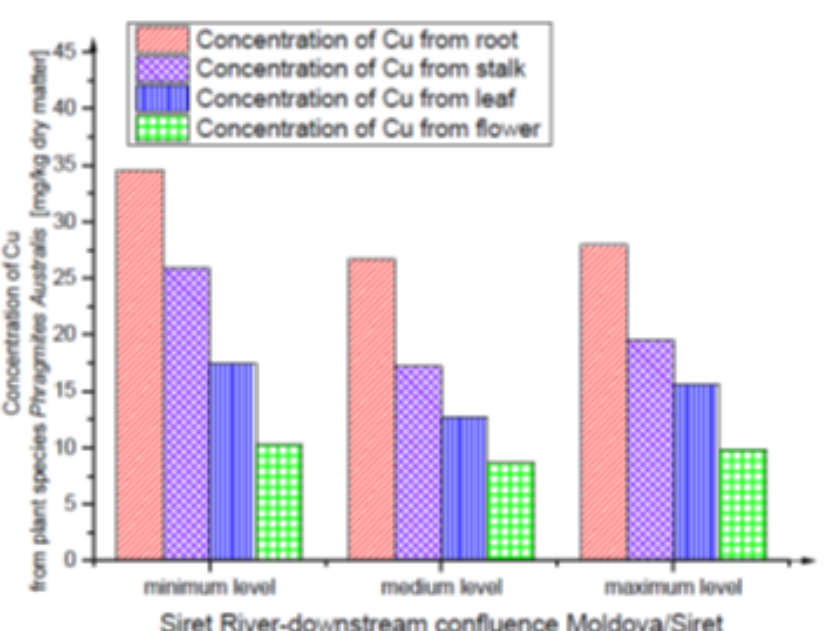

Fig. 6. The absorption capacity of copper from the soil in the case of Phragmites Australis plant species (root, stalk, leaf, flower) in the sampling point Siret River - downstream confluence Moldova/ Siret

water interface, it was $30.05 \%$ lower than in the root of plant);

b -leaf (for the minimum level of soil-water interface, it was $49.37 \%$ lower than in the root of plant; for the medium level of soil-water interface, it was $52.58 \%$ lower than in the root of plant and for the maximum level of soil-water interface, it was $44.23 \%$ lower than in the root of plant);

c-flower (for the minimum level of soil-water interface, it was $70.19 \%$ lower than in the root of plant; for the medium level of soil-water interface, it was $67.42 \%$ lower than in the root of plant and for the maximum level of soilwater interface, it was $64.68 \%$ lower than in the root of plant).

The percentage values of the lead concentration determined in the stem, leaf and flower compared with the root of the Phragmites Australis plant species for the Table 2

THE EXPERIMENTAL VALUES DETERMINED FOR ABSORPTION CAPACITY OF COPPER AND LEAD FROM THE SOIL IN THE CASE OF PHRAGMITES AUSTRALIS PLANT SPECIES (ROOT, STALK, LEAF, FLOWER) IN THE SAMPLING POINT SIRET RIVER DRAGESTI

\begin{tabular}{|c|c|c|c|c|c|c|c|c|c|}
\hline \multirow{2}{*}{ Location } & \multirow{2}{*}{ Level } & \multicolumn{4}{|c|}{$\begin{array}{c}\mathrm{Cu} \\
{[\mathrm{mg} / \mathrm{kg} \text { dry matter] }}\end{array}$} & \multicolumn{4}{|c|}{$\begin{array}{c}\mathrm{Pb} \\
{[\mathrm{mg} / \mathrm{kg} \mathrm{dry} \text { matter] }}\end{array}$} \\
\hline & & Root & Stalk & Leaf & Flower & Root & Stalk & Leaf & Flower \\
\hline \multirow{3}{*}{$\begin{array}{l}\text { downstream } \\
\text { Moldova } \\
\text { River- } \\
\text { Roman city }\end{array}$} & $\begin{array}{l}\text { minimum level of } \\
\text { soil-water } \\
\text { interface }(0 \mathrm{~cm})\end{array}$ & 19.23 & 15.32 & 8.95 & 2.7 & 7.49 & 2.91 & 1.09 & 0.25 \\
\hline & $\begin{array}{l}\text { medium level of } \\
\text { soil-water } \\
\text { interface }(50 \mathrm{~cm})\end{array}$ & 22.46 & 18.69 & 10.36 & 3.29 & 6.24 & 2.13 & 0.82 & 0.11 \\
\hline & $\begin{array}{l}\text { maximum level of } \\
\text { soil-water } \\
\text { interface }(100 \mathrm{~cm})\end{array}$ & 21.95 & 18.25 & 9.45 & 3.12 & 5.57 & 1.95 & 0.46 & 0.09 \\
\hline
\end{tabular}




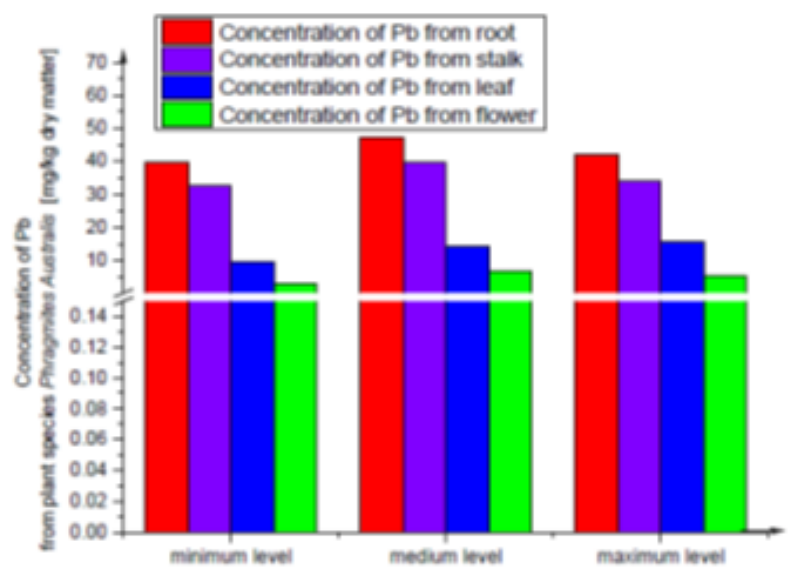

Siret River-downstream confluence Moldova/Siret

Fig. 7. The absorption capacity of lead from the soil in the case of Phragmites Australis plant species (root, stalk, leaf, flower) in the sampling point Siret River - downstream confluence Moldova/Siret

sampling point Siret River - downstream confluence Moldova/Siret, was (Figure 7):

a -steam (for the minimum level of soil-water interface, it was $82.64 \%$ of concentration from the root of plant; for the medium level of soil-water interface, it was $83.72 \%$ of concentration from the root of plant and for the maximum level of soil-water interface, itwas $80.57 \%$ of concentration from the root of plant);

$\mathrm{b}$-leaf (for the minimum level of soil-water interface, it was $24.26 \%$ of concentration from the root of plant; for the medium level of soil-water interface, it was $30.34 \%$ of concentration from the root of plant and for the maximum level of soil-water interface, itwas $37.14 \%$ of concentration from the root of plant);

c-flower (for the minimum level of soil-water interface, it was $8.13 \%$ of concentration from the root of plant; for the medium level of soil-water interface, it was $14.49 \%$ of concentration from the root of plant and for the maximum level of soil-water interface, itwas $12.64 \%$ of concentration from the root of plant).

Table 2 present the experimental values determined for absorption capacity of copper and lead from the soil in the case of Phragmites Australis plant species (root, stalk, leaf, flower) in the sampling point Siret River Dragesti.

The highest absorption capacity of copper from the soil, in downstream Siret River - Dragesti, was detected in the root of Phragmites Australis plantspecies (for the minimum level of soil-water interface, it was $712.22 \%$ higher than in the flower of plant), whereas the lowest absorption capacity levels of copper were observed in its leaf and flower.

The highest absorption capacity of lead from the soil, in downstream Siret River - Dragesti, was detected in the root of Phragmites Australis plant species (for the maximum level of soil-water interface, it was $6188.88 \%$ higher than in the flower of plant), whereas the lowest absorption capacity levels of lead were observed in its leaf and flower.

\section{Conclusions}

The highest absorption capacity of copper from the soil, in all points analyzed, was detected in the root of Phragmites Australis plant species $(8.34 \div 34.53 \mathrm{mg} / \mathrm{kg}$ dry matter), whereas the lowest absorption capacity levels of copper were observed in its leaf and flower.

In case of lead the highest absorption capacity from the soil, in all points analyzed, was detected in the root of Phragmites Australis plant species $(2.75 \div 47.25 \mathrm{mg} / \mathrm{kg}$ dry matter).
Comparing the absorption capacity of metals from the soil in the case of Phragmites Australis plant species it was observed that it is a very good accumulator of copper and lead in the root of the plant.

Phragmites Australis plant species proved to be a very good accumulators of metals, especially in their roots, a fact which shows that they can be used in soil phytoremediation processes, particularly in continuous phytoextraction and induced phyto-extraction processes for the removal of heavy metals from contaminated soils.

\section{References}

1. JOSEPH, R.D., DOKE, K.M., KHAN, E.M., J ournal of Herbal Medicine and Toxicology, 5, 2011, p.19.

2. DRAGOVIC, S., MIHAILOVIC, N., GAJIC, B., Chemosphere, 72, 2008, p. 491.

3.RADU, C., Studies and research on the ecological impact of residual soil pollution by heavy metals on tributaries' banks from the Siret hydrographic basin, phD Thesis, Vasile Alecsandri University of Bacau, Romania, 2015. p. 58.

5.KO, I., CHANG, Y., LEE, C., KIM, W., J ournal of Hazardous Materials, 127,2005, p. 1.

6.BELCIU, M.C., NEDEFF, V., CHITIMUS, A.D., BARSAN, N., RUSU, D., Journal of Engineering Studies and Research, 22, no. 1, 2016, p. 15. 7. KOSTIC, D., MITIC, S., ZARUBICA, A., MITIC, M., VELICKOVIC, J., RANDJELOVIC, S., 65, no. 2, 2011, p. 165.

8.RADU, C., CHITIMUS, A.D., TURCU, M., ARDELEANU, G., BELCIU M, Environmental Engineering and Management J ournal, 13, no. 7, 2014, p. 1687.

9.RADU, C., NEDEFF, V., CHITIMUS, A.D., J ournal of Engineering Studies and Research, 19, 2, 2013, p. 89.

10.AL-MOMANI, I.F., J ordan J ournal of Chemistry, 4, 2009, p. 77.

11. BELCIU, M.C., NEDEFF, V., CHITIMUS, A.D., RADU, J ournal of Engineering Studies and Research, 20, no. 1, 2017, p. 23.

12.ACKOVA, D.G., Plant Science Today, 5, no. 1, 2018, p. 14.

13.CHITIMUS, A.D., NEDEFF, V., LAZAR, G., MACARESCU, B., MOSNEGUTU, E., Journal of Engineering Studies and Research, 17, no. 1, 2011, p. 13.

14.NAGAJYOTI, P.C., LEE, K.D., SREEKANTH, T.V.M., Environmental Chemistry Letter, 8, 2010, p.199.

15.MUSCALU (PLESCAN), O.M., NEDEFF, V., CHITIMUS, A.D., PARTAL, E., MOSNEGUTU, E., RUSU, I.D., Rev. Chim. (Bucharest), 69, no. 11, 2018, p. 3106.

16.GULERYUZ, G., ARSLAN, H., CELIK, C., GUCER, S., KENDALL, M., Water Air Soil Pollution, 195, 2008, p. 275.

17.KIM, Y., KIM, B.K., KIM, K., Environmental Earth Sciences, 60, 2009, p. 943.

18.MUSCALU (PLE'CAN), O.M., NEDEFF, V., CHIIMUS, A.D., PARTAL, E., BARSAN, N., RUSU, I.D, Rev. Chim. (Bucharest), 70, no. 2, 2019, p. 536-542.

19.CHITIMUS, A.D., BARSAN, N., NEDEFF, V., MOSNEGUTU, E., MUSCALU (PLESCAN), 0., 17th International Multidisciplinary Scientific GeoConference SGEM 2017, 17, no. 51, 2017, p. 859.

20.WARNE, M.S., HEEMSBERGEN, D., STEVENS, D., COZENS, G., WHATMUFF, M., BROOS, K., BARRY, G., BELL, M., NASH, D., PRITCHARD, D., PENNEY, N., Environmental Toxicology Chemistry, 27, 2008, p. 786.

21.MUSCALU (PLE'CAN), O.M., NEDEFF, V., PARTAL, E., MOSNEGUTU, E., SANDU, I.G., SANDU, I., BARSAN, N., RUSU, D., Rev. Chim. (Bucharest), 70, no. 5, 2019, p. 1726.

22.CHITIMUS, A.D., RADU, C., NEDEFF, V., MOSNEGUTU, E., BARSAN, N., Scientific Study \& Research Chemistry \& Chemical Engineering, Biotechnology, Food Industry, 17, no. 4, 2016, p. 381.

23.VERSIEREN, L., EVERS, S., ABDELGAWAG, H., ASARD, H., SMOLDERS,

E., Environmental Toxicology Chemistry, 36, 2017, p. 220.
4.ABDERRAHIM, G., European J ournal of Scientific Research, 32, 2009, 
24.CHITIMUS, A.D., MOSNEGUTU, E., NICOLESCU, M.C., TURCU M., BELCIU, M.C., ARDELEANU, G., Environmental Engineering \& Management J ournal, 13, no. 7, 2014, p. 1581.

25.CHARKRAVARTY, M., PATGIRI, A.D., J ournal of Human Ecology, 27, 2009, 63.

26.CHITIMUS, A.D., NEDEFF, V., MOSNEGUTU, E., PANAINTE, M., Environmental Engineering and Management J ournal, 11, no. 12, 2012, p. 2163.

27.SINGH, R., GAUTAM, N., MISHRA, A., GUPTA, R., Indian Journal Pharmacology, 43, 2011, p. 246.

28.CHITIMUS, D., COCHIORCA, A., NEDEFF, V., MUSCALU, O., BARSAN, N., Proceeding of the International Multidisciplinary Scientific GeoConference Surveying Geology and Mining Ecology Management, SGEM, 18, 2018, p. 671.

29.LIANG, J., CHEN, C., SONG, X., HAN, Y., LIANG, Z., International J ournal of Electrochemical Science, 6, 2011, p. 5314.

30. CHITIMUS, A.D., NEDEFF, V., LAZAR, G., Actual Stage in the Soil Remediation, Journal of Engineering Studies and Research, 17, no. 4, 2011, p. 24.

31.J AWAD, I.M., Pakistan J ournal of Nutrition, 9, no. 7, 2010, p 683-685. 32.ZHELJ AZKOV, V.D., JELIAZKOVA, E., KOVATCHEVA, N., DZHURMANSKI, A., Environmental \& Experimental Botany, 64, no. 3, 2008, p. 207.

33.ZHENG, N., WANG, Q., ZHENG, D., Science of the Total Environment, 383, no. 1, 2007, p. 81.

34.CHITIMUS, A.D., NEDEFF, V., SANDU, I., RADU, C., MOSNEGUTU, E., SANDU, I.G., BARSAN, B., Rev. Chim. (Bucharest), 70, no. 7, 2019, p. 2545 .
35.CHITIMUS, A.D., NEDEFF, V., SANDU, I., RADU, C., MOSNEGUTU, E., SANDU, I.G., BARSAN, B., Rev. Chim. (Bucharest), 70, no. 8, 2019, p. 3058.

36.ARDELEANU, G., TOMOZEI, C., IRIMIA, O., PANAINTE-LEHADUS, M., 16th International Multidisciplinary Scientific GeoConference SGEM 2016, SGEM 2016 Conference Proceedings, 3, 2, 2016, p. 763.

37.IRIMIA, O., TOMOZEI, C., PANAINTE LEHADUS, M., MOSNEGUTU, E., BARSAN, N., Environmental Engineering and Management Journal, 12, no. 1, 2013, p. 35.

38.DAESCU, A.I., HOLBAN, E., BOBOC, M.G., RAISCHI, M.C., MATEI, M., ILIE, M., DEAK, G., DAESCU, V., J ournal of Environmental Protection and Ecology, 18, no. 1, 2017, p. 304.

39. IONESCU, P., DEAK, G., DIACU, E., RADU, V.M., Rev. Chim (Bucharest), 67, no. 11, 2016, p. 2148.

40. HOLBAN, E., DEAK, G.Y., DAESCU, V., DIACU, E., DAESCU, A.I., TANASE, G.S., MARINESCU, P., SIRBU, C., PACEAGIU, J., J ournal of Environmental Protection and Ecology, 16, no. 2, 2015, p. 479.

41. RADU, V.M., IONESCU, P., DEAK, G.Y., J ournal of Environmental Protection and Ecology, 16, no. 2, 2015, p. 610.

42. ILIE, M., GHITA, G., MATEI, M., DEAK, G.Y., DUMITRU, D.F., MONCEA, A.M., MARINESCU, F., LASLO, L.A., FRONESCU, D.F., DAESCU, V., J ournal of Environmental Protection and Ecology, 19, no. 2, 2018, p. 646.

43. *** Atomic absorption spectrometry (AAS) ZEEnit 700, Operating Manual, 2009

Manuscript received: 12.11 .2019 